\title{
THE DYNAMIC EVOLUTION OF INTERNATIONAL LAW - THE CASE FOR THE MORE PURPOSEFUL DEVELOPMENT OF CUSTOMARY INTERNATIONAL LAW
}

\section{Bill Campbell}

\begin{abstract}
A fundamental underpinning of the ongoing relevance of international law is that of its ability to adapt and change to meet new developments and challenges including new technology, new (or newly developing) threats to both the public and the international order and newly developed practices, for example trans-border corporate and taxation practices. How then to effect that change?

The timely negotiation of treaties to deal with the subject matter of these new developments and challenges would be ideal but can be difficult due to a number of factors. The answer could lie in the more purposeful and expeditious development of customary international law - that is, by taking coordinated action, and by publicising that action and its legal basis.
\end{abstract}

This will not result in changes to the law of the detail that might be expected in a treaty, but it could address particular issues of moment. Indeed, individual states may well see themselves as having no option but to take action to meet time sensitive and critical aspects of new developments and global challenges either alone or in concert with others with a view to the development of a more widespread custom. Initial characterisation of some such action as "illegal but justified" (or words along those lines), whilst a contradiction in terms, does at the very least point to a real need for a change in the law. An example of such purposeful action may well be the development of the customary international law of self-defence to support the use of force against non-state actors in certain circumstancessuch as the force used by a number of states against the Islamic State of Iraq and the Levant (ISIL) in Syria on the basis of the collective self-defence of Iraq.

* QC; formerly General Counsel (International Law), Office of International Law, Australian AttorneyGeneral's Department. 
The participants in the development and practice of international law are states and their governments, intergovernmental organisations - both regional and international, international courts and tribunals, non-government organisations, academia and other individuals. Despite increasing participation by the other players, states remain in effective control.

It is states that negotiate and become parties to treaties. It is the practice of states that underpins the development of customary international law. It is states for the most part that decide whether or not to comply with international law. And, leaving aside categories of individual responsibility under international law, it is states that bear responsibility for non-compliance with international law. It follows that any binding solution to what might be perceived to be lacunae in the international law necessary to meet modern challenges can only be perfected through the actions of states.

However, there are impediments to the state-based system of international law-making particularly with regards to treaties. Without wishing to be comprehensive they include: a dogged adherence to the status quo; national interest (some would say national self-interest); the absence of a perceived or recognised common interest or problem to be addressed; and ideological differences.

That is not to deny that there are examples of treaties negotiated in relatively recent times which have a high state membership - instances being various human rights treaties such as the Convention on the Rights of the Child and the Convention on the Rights of Persons with Disabilities, the United Nations Convention on the Law of the Sea, the Arms Trade Treaty and the various climate related treaties and protocols. ${ }^{1}$

However, it is getting harder to negotiate truly effective treaties particularly in what are perceived to be contentious or urgent subject areas such as counter-terrorism, cyber and new issues of the use of force including in outer space. Moreover, there is reluctance on the part of many states to revisit important elements of existing treaties in need of change either by way of amendment or the adoption of a replacement instrument. This, in part, is because of the perceived prospect of a lengthy and fruitless negotiation and also because of the fears of opening a Pandora's box in terms of content or the unravelling of a delicate package underpinning the original treaty.

1 Convention on the Rights of the Child 1577 UNTS 3 (opened for signature 20 November 1989, entered into force 16 November 1990); Convention on the Rights of Persons with Disabilities 2515 UNTS 3 (opened for signature 13 December 2006, entered into force 3 May 2008); United Nations Convention on the Law of the Sea 1833 UNTS 3 (opened for signature 10 December 1982, entered into force 16 November 1994); and Arms Trade Treaty [2014] ATS 42 (opened for signature 3 June 2013, entered into force 24 December 2014). 
So what is the solution to developing international law in such areas? The solution could be the development of customary international law by states in a more purposeful and coordinated manner. ${ }^{2}$

It might be said that the development of customary international law is not something that can be organised and that any attempts to do so would amount to a manipulation of the international system and inherently involve breaches of existing law. ${ }^{3}$ On the first point, the two elements of customary international law as described by Professor (now Judge) Crawford - "is there a general practice" and "is it accepted as international law?" - by definition guard against manipulation. ${ }^{4}$ Indeed, these two elements and associated principles that currently are under consideration by the International Law Commission (ILC) may well act as a brake on the rapid development of customary international law in many areas. ${ }^{5}$ Responding to the second point concerning breach, state practice has to start somewhere. There are many examples of initial state practice that were regarded as going beyond international law and which subsequently expanded to form the basis of a rule of customary international law - one example being the development of fishing zones beyond the territorial sea.

Before moving on to an example of the more purposeful development of customary international law by states it would be appropriate to mention two other means of enhancing the progression of existing customary international law.

The first means is through the development of manuals by international organisations and groups of experts. Existing examples include International Committee of the Red Cross publications:

2 Scharf notes that "while one might tend to think of customary international law as growing only slowly, in contrast to the more rapid formation of treaties, the actual practice of the world community in modern times suggests that the reverse is more often the case": Michael P Scharf "Accelerated Formation of Customary International Law" (2014) 20 ILSA Journal of International \& Comparative Law 305 at 309.

3 Scharf also notes that states "may fear a concept of law formation that appears more revolutionary than evolutionary": at 341. Roberts identifies a number of perspectives including one that views modern approaches to custom as an opportunity for legal and political abuse and also Michael Reisman's characterisation of the increased dependence on custom as a "great leap backwards" designed to serve the interests of powerful states: Anthea Roberts "Traditional and Modern Approaches to Customary International Law: A Reconciliation" (2001) 95 AJIL 757 at 767.

4 James Crawford Brownlie's Principles of Public International Law (8th ed, Oxford University Press, Oxford, 2012) at 23. Professor Crawford also has commented that: "The problem with establishing customary international law is that it seems impossible": James Crawford Chance, Order, Change: The Course of International Law (Martinus Nijhoff, Leiden, 2014) at 49.

5 International Law Commission Identification of Customary International Law: Text of the draft conclusions as adopted by the Drafting Committee on the second reading UN Doc A/CN.4/L.908 (17 May 2018). Under draft Conclusion 8 state practice "must be sufficiently widespread and representative, as well as consistent" but "no particular duration is required". 
Customary International Humanitarian Law Study, ${ }^{6}$ Interpretive Guidance on the Notion of Direct Participation in Hostilities ${ }^{7}$ and the updated commentaries on the Geneva Conventions. ${ }^{8}$ Other examples include the Tallin Manual 2.0 on the International Law Applicable to Cyber Operations ${ }^{9}$ and the Manual on International Law Applicable to Military Uses of Outer Space (MILAMOS) Project. ${ }^{10}$ The latter project has as its aim: ${ }^{11}$

... to develop a widely-accepted manual clarifying the fundamental rules applicable to the military use of outer space, in times of peace, as well as in periods of tension, and during armed conflict.

As noted above, this is an area in which it would be difficult to negotiate a detailed treaty.

The second means is the work of the ILC. A prime example in this respect is the ILC's Articles on the Responsibility of States for Internationally Wrongful Acts that were adopted on 31 May 2001. ${ }^{12}$ These draft articles were annexed to United Nations (UN) General Assembly Resolution 56/83 on 12 December of the same year and presented to states as being "without prejudice to the question of their future adoption". ${ }^{13}$ Individual articles are now widely regarded as either reflective of customary international law or as likely to develop into customary international law and have been referred to and relied upon on innumerable occasions by international courts and tribunals as well as by governments. ${ }^{14}$

6 Jean-Marie Henckaerts and Louise Doswald (eds) Customary International Humanitarian Law (International Committee of the Red Cross, Cambridge University Press, New York, 2005).

7 Nils Melzers (ed) Interpretative Guidance on the Notion of Direct Participation in Hostilities under International Humanitarian Law (International Committee of the Red Cross, Geneva, 2009).

8 See for example Commentary: Geneva Convention for Amelioration of the Condition of the Wounded and Sick in Armed Forces in the Field (2016). While a number of states have expressed concern over important points of detail in the International Committee of the Red Cross Customary International Law and Direct Participation in Hostilities publications, there is no doubt that they have been, and will continue to be referred to by international courts and tribunals thus giving imprimatur to the principles they contain.

9 Michael N Schmitt (ed) Tallin Manual 2.0 on the International Law Applicable to Cyber Operations (Cambridge University Press, Cambridge, 2017).

10 McGill University "Manual on International Law Applicable to Military Uses of Outer Space" <www.mcgill.ca>.

11 McGill University, above n 10.

12 For the text of the Articles as well as a commentary see James Crawford The ILC's Articles on State Responsibility: Introduction, Text and Commentaries (Cambridge University Press, Cambridge, 2002).

13 Responsibility of States for internationally wrongful acts GA Res 56/83 (2002) at [3].

14 Unfortunately, a minority of states are committed to translating the Articles into a treaty, a move that could well see the unravelling of a comprehensive and largely accepted body of rules on a matter that permeates 
In addition to these mechanisms, customary international law could be developed by states in a planned and purposeful manner to respond more expeditiously to particular new challenges on the international plane, in circumstances where it may be unlikely that a treaty could be developed in the time necessary to meet those challenges. One recent possible example concerns the legal basis for responding to the threat posed by well-organised non-state actors operating out of one country ("the host state") and carrying out armed attacks within the borders of another country ("the target state"). Indeed, it was just that circumstance that led to the seminal exchange of correspondence on the limits of self-defence between the United States (Secretary of State Webster) and the United Kingdom (Lord Ashburton) following The Caroline incident in $1837 .{ }^{15}$ However, the law of self-defence as it had developed subsequently focussed on attacks, or an imminent threat of attack by one state upon another state.

The Nicaragua Case set a high threshold as to the required degree of host state support of nonstate actors before an armed attack could be said to have taken place justifying an action in selfdefence by the target state within the borders of the host state: ${ }^{16}$

There appears now to be general agreement on the nature of the acts which can be treated as constituting armed attacks. In particular, it may be considered to be agreed that an armed attack must be understood as including not merely action by regular armed forces across an international border, but also "the sending by or on behalf of a State of armed bands, groups, irregulars or mercenaries, which carry out acts of armed force against another State of such gravity as to amount to" (inter alia) an actual armed attack conducted by regular forces, "or its substantial involvement therein".

international law. This risk is no better encapsulated than by the views expressed by the United Kingdom in the UN:

It would be dangerous to press ahead with a convention during the process of the natural development of customary international law. The very premise upon which codification was founded, namely that customary international law was settled, would be absent. The process of elaboration a convention would highlight and exacerbate the differences of approach, thereby threatening the coherence that the articles sought to and indeed did instil. ... A convention which adopted the articles would be premature and likely counterproductive. A better course of action would be to defer discussion until the remaining issues were resolved, and to return to the topic once customary international law was settled.

UN Sixth Committee Summary of record of the 9th meeting UN Doc A/C.6/71/SR.9 (7 November 2016) at $52-53$.

15 See Gillian D Triggs International Law, Contemporary Principles and Practices (2nd ed, LexisNexis, Chatswood, 2011) at 615.

16 Military and Paramilitary Activities in and against Nicaragua (Nicaragua v United States of America) (Merits) [1986] ICJ Rep 14 at 103-104. 
The obvious difficulty with this attribution standard of a "sending by or on behalf of a State" is that it does not permit of an action in self-defence in circumstances where the host state, while not procuring or providing assistance to the relevant non-state actors, takes no steps to prevent attacks by them emanating from its territory.

As noted by Treves, "the urgency of coping with widespread sentiments of moral outrage regarding crimes committed in conflicts" can be a catalyst for customary rules coming into existence rapidly. ${ }^{17}$ That catalyst in the case of the rapid development of the law relating to use of force against non-state actors within the territory of another state was the 11 September 2001 terrorist attacks in the United States. $^{18}$

Soon after those attacks took place, Professor Greenwood noted the gravity of the threat posed by acts of terrorism perpetrated by non-state actors: ${ }^{19}$

Since the events of 11 September showed - if, indeed, the matter were ever in any doubt - that a terrorist organization operating outside the control of any state is capable of causing death and destruction on a scale comparable with that of regular military action by a state, it would be a strange formalism which regarded the right to take military action against those who caused or threatened such consequences as dependent upon whether their acts could somehow be imputed to a state. ... the famous Caroline dispute, which is still regarded as the classical definition of the right of self-defence in international law, shows that an armed attack need not emanate from a state.

The 2005 Chatham House Principles of International Law on the Use of Force by States in SelfDefence progressed the development of a legal basis to respond to such attacks. The introduction to that document stated that: ${ }^{20}$

17 Tullio Treves "Customary International Law" in Max Planck Encyclopaedia of Public International Law (Martinus Nijhoff, Leiden, 2006) at [25]. On the other hand, the note of caution expressed by Gassama is pertinent when considering development of the law in times of conflict: "It is always easy, at times of great international turmoil, to spot a turning point that is not there": Ibrahim Gassama "International Law at a Grotian Moment: The Invasion of Iraqi in Context" (2004) 18 Emory International Law Review 1 at 30.

18 See Jutta Brunnée and Stephen J Toope "Self-Defence against Non-State Actors: Are Powerful State Actors Willing but Unable to Change International Law?" (2018) ICLQ 263 at 267.

19 Christopher Greenwood "International Law and the 'War against Terrorism'" (2002) 78 International Affairs at 307-308. This passage was cited by Gleeson CJ of the High Court of Australia in support of his conclusion that the defence power under the Australian Constitution could be used to support domestic counter-terrorism legislation: Thomas v Mowbray (2007) 233 CLR 307 at 324-325.

20 Elizabeth Wilmshurst Principles of International Law on the Use of Force by States in Self-Defence (The Royal Institute of International Affairs, October 2005) at 2. 
While the Principles are intended to give a clear representation of the current principles and rules of international law, the law in this area is politically and legally contentious, and the interpretation of the Principles and their application to particular cases will rarely be without difficulty.

Principle 6 dealt with self-defence against non-state actors: ${ }^{21}$

The right of self-defence applies also to attacks by non-state actors.

- In such a case the attack must be large scale.

- If the right of self-defence in such a case is to be exercised in the territory of another state, it must be evident that that state is unable or unwilling to deal with the non-state actors itself, and that it is necessary to use force from outside to deal with the threat in circumstances where the consent of the territorial state cannot be obtained.

- Force in self-defence directed against the government of the state in which the attacker is found may be justified only in so far as it is necessary to avert or end the attack, but not otherwise.

The next public step in the development of rules concerning use of force against non-state actors was the publication by Sir Daniel Bethlehem ${ }^{22}$ of the "Principles Relevant to the Scope of a State's Right of Self-Defense Against an Imminent or Actual Armed Attack by Nonstate Actors". ${ }^{23}$ The author stated that they were proposed with the intention of stimulating debate on the issues and "do not purport to reflect a settled view of the law or the practice of any state". ${ }^{24}$ However, he made the following points, relevant to this article, about the not so public steps leading to their development: ${ }^{25}$

While an important strand of the debate has taken place in academic journals and public forums, there has been another strand, largely away from the public gaze, within governments and between them, about

21 At 11 (footnotes omitted).

22 A former Legal Adviser to the United Kingdom Foreign and Commonwealth Office.

23 Daniel Bethlehem "Principles Relevant to the Scope of a State's Right of Self-Defense Against an Imminent or Actual Armed Attack by Nonstate Actors" (2012) 106 AJIL 770.

24 At 775 .

25 At 770 and 773. The aspect of the debate taking place "largely away from the public gaze, within governments and between them" is discussed more fully in Daniel Bethlehem "The Secret Life of International Law" (2012) 1(1) CJICL 23. His concluding observation in that article "would therefore simply be that in very many cases one cannot make assumptions about what the law is, or reach considered conclusions on whether conduct is lawful or unlawful, until one has considered the invisible conduct, as well as the visible": at 36. See also at 24 and 27. Brunnée and Toope, above n 18, at 283, allude to the possibility of purposeful attempts of norm creation in relation to an unwilling and unable principle in the following terms: "One might speculate that academic articles and policy briefs were consciously part of a process of norm entrepreneurship, building up claims around necessity and State practice to validate the unwilling or unable standard." See also at $275, \mathrm{n}$ 65. 
what the appropriate principles are, and ought to be, in respect of such conduct. Insofar as these discussions have informed the practice of states and their appreciations of legality, they carry particular weight, being material both to the crystallization and development of customary international law and to the interpretation of treaties.

Aspects of these ... discussions have periodically become visible publicly through official statements and speeches, evidence to governmental committees, reports of such committees, and similar documents. Other aspects have to be deduced from the practice of states - which, given the sensitivities, is sometimes opaque.

$\ldots$

The principles do not reflect a settled view of any state. ... They have nonetheless been informed by detailed discussions over recent years with foreign ministry, defense ministry, and military legal advisers from a number of states who have operational experience in these matters. The hope, therefore, is that the principles may attract a measure of agreement about the contours of the law relevant to the actual circumstances in which states are faced with an imminent or actual armed attack by nonstate actors.

For present purposes, it will suffice to mention the following four principles: ${ }^{26}$

1. States have a right of self-defense against an imminent or actual armed attack by nonstate actors.

10. Subject to the following paragraphs, a state may not take armed action in self-defense against a nonstate actor in the territory or within the jurisdiction of another state ("the third state") without the consent of that state.

11. The requirement for consent does not operate in circumstances in which there is a reasonable and objective basis for concluding that the third state is colluding with the nonstate actor or is otherwise unwilling to effectively restrain the armed activities of the nonstate actor ...

12. The requirement for consent does not operate in circumstances in which there is a reasonable and objective basis for concluding that the third state is unable to effectively restrain the armed activities of the nonstate actor such as to leave the state that has a necessity to act in self-defense with no other reasonably available effective means to address an imminent or actual armed attack.

26 At 775-776 (emphasis added, footnotes omitted). 
The principles put forward by Bethlehem were the subject of criticism ${ }^{27}$ though as noted by Bethlehem in response to that criticism "a good deal of support for the principles and their publication has been voiced, notably by government lawyers who are grappling with these issues". ${ }^{28}$

The position of Australia and that of a number of other countries is that the customary international law of self-defence has developed to enable action in self-defence to be taken not only against states but also against non-state actors located within a non-consenting host state provided certain criteria are met. It is on this basis that Australia and a number of other countries conduct air operations against ISIL (Daesh) in Syria in the collective self-defence of Iraq. ${ }^{29}$

In addition to the standard criteria underpinning an action in collective self-defence, ${ }^{30}$ collective self-defence against non-state actors requires that the state in which they are based is either unable or unwilling to control the actions of the relevant non-state actors located within its borders. In terms of state practice (albeit limited), application of that criterion is reflected in the notifications to the UN Security Council by a number of countries under Article 51 of the UN Charter in relation to their actions against ISIL in Syria. For example, the relevant segment of Australia's notification stated: ${ }^{31}$

Article 51 of the Charter of the United Nations recognizes the inherent right of States to act in individual or collective self-defence where an armed attack occurs against a Member of the United Nations. States

27 See Dapo Akande and Thomas Lieflander "Clarifying Necessity, Imminence, and Proportionality in the Law of Self-Defense" (2013) 107 AJIL 563; Dire Tladi "The Nonconsenting Innocent State: The Problem with Bethlehem's Principle 12" (2013) 107 AJIL 570; and Mahmoud Hmoud "Are New Principles Really Needed? The Potential of the Established Distinction Between Responsibility for Attacks by Nonstate Actors and the Law of Self-Defense" (2013) 107 AJIL 576.

28 Daniel Bethlehem "Principles of Self-Defense-A Brief Response" (2013) 107 AJIL 579 at 581.

29 This position of Australia is reflected in an article by its then Attorney-General George Brandis "It's a war of self-defence" The Australian (10 September 2015) at 12.

30 An actual or imminent armed attack, no effective means to address the attack other than the use of force and a request for assistance from the state under threat. In addition, the right of self-defence once established is not unconstrained. The force used must be necessary to address the threat and be proportionate to it.

31 Letter dated 9 September 2015 from the Permanent Representative of Australia to the United Nations addressed to the President of the Security Council UN Doc S/2015/693 (9 September 2015). See also Letter dated 23 September 2014 from the Permanent Representative of the United States of America to the United Nations addressed to the Secretary-General UN Doc S/2014/695 (23 September 2014); and Letter dated 31 March 2015 from the Chargé d'affaires ai of the Permanent Mission of Canada to the United Nations addressed to the President of the Security Council UN Doc S/2015/221 (31 March 2015). The notifications made by a number of other states used similar wording (for example Turkey in its notification of 24 July 2015 used the term "neither capable of nor willing" and Germany and Belgium in their respective notifications of 10 December 2015 and 9 June 2016 referred to ISIL occupying Syrian territory over which Syria "does not, at this time exercise effective control"). Yet other states (for example, Netherlands, Denmark and the United Kingdom) asserted the right to take action against ISIL in Syria by way of collective self-defence without giving a detailed explanation of the legal basis for doing so. 
must be able to act in self-defence when the Government of the State where the threat is located is unwilling or unable to prevent attacks originating from its territory. The Government of Syria has, by its failure to constrain attacks upon Iraqi territory originating from ISIL bases within Syria, demonstrated that it is unwilling or unable to prevent those attacks.

This development in the law of self-defence is not uniformly accepted ${ }^{32}$ - least of all by Syria. ${ }^{33}$ States may well differ as to whether a particular principle - for example, the "unable or unwilling" principle - has moved from being de lege ferenda to lex lata or even reached the first stage and perhaps this is in part reflective of the "impossibility" to which Judge Crawford makes reference. ${ }^{34}$ Brunnée and Toope are circumspect in their characterisation of the stage reached in relation to the unwilling or unable principle in stating: ${ }^{35}$

Great caution is warranted before accepting the argument that changes in customary international law can

be produced through the practice of a small number of lead-States combined with the alleged acquiescence

of a largely silent majority.

Be that as it may, there was an undoubted need for the development of the law in this area. The development of a treaty in a timely manner was not a realistic proposition. One only has to recall the stalled negotiations on the Comprehensive Convention on International Terrorism to understand why the timely negotiation and entry into force of a treaty regime dealing with self-defence against use of force by non-state actors was not a viable option. Nor, for obvious reasons, could it be assumed that there would be a UN Security Council Resolution authorising such action in many circumstances.

Other areas in which there either has been, or could be, more timely and purposeful developments in customary international law include countering cyber-threats where the developing law is going

32 The amount of practice necessary to underpin a custom is variable. In this respect Roberts, above n 3, at 767 has noted that "most customs are found to exist on the basis of practice by fewer than a dozen states" This more general conclusion is to be contrasted with that of Brunnée and Toope, above n 18, at 277 in the context of the unwilling or unable standard that "the rather mixed, and largely self-referential, practice of a small number of primarily Western States cannot suffice to shift customary international law in the face of the silence of a majority of States on the operations against IS in Syria".

33 Identical letters dated 21 September 2015 from the Permanent Representative of the Syrian Arab Republic to the United Nations addressed to the Secretary-General and the President of the Security Council UN Doc S/2015/727 (22 September 2015).

34 See Crawford, above n 4. See also the reference by Brunnée and Toope, above n 18, at 279 to the diffuse, fluid nature of the public international law process making it "harder to identify the precise point at which a new law has been promulgated".

35 Brunnée and Toope, above n 18, at 282. In this respect see also International Law Commission, above n 5, at Draft Conclusion 10.3 on the Identification of Customary International Law: "Failure to react over time to a practice may serve as acceptance as law (opinion juris), provided that States were in a position to react and the circumstances called for some reaction." 
down the path of adopting principles analogous to the law of armed conflict; a second would be the law relating to the hot pursuit of vessels which is sorely in need of change to take account of developments in technology; and a third would be humanitarian intervention, which was recently relied upon by the United Kingdom as the legal basis for its participation in armed strikes in Syria for the avowed purpose of degrading Syria's chemical weapons and deterring their future use. ${ }^{36}$ A more coordinated and purposeful development of customary international law by states remains a real option to achieve targeted obligations binding on states in areas of pressing need such as these.

36 Karen Pierce, United Kingdom Permanent Representative to the United Nations "Our military action will degrade the Syrian regime's chemical weapons use" (statement to the Security Council, 14 April 2018). 
